\title{
Особливості тактики хірургічного лікування первинних доброякісних пухлин серця
}

\author{
Вітовський Р. М., Ісаєнко В. В., Онищенко В. Ф., Піщурін А. А., Дядюн Д. Н. \\ ДУ «Національний інститут серцево-судинної хірургії імені М. М. Амосова НАМН України» (Київ)
}

\begin{abstract}
Частота діагностики первинних пухлин серця (ППС), з яких понад $80 \%$ є морфологічно доброякісними пухлинами, становить 0,09-1,9\% у загальному числі госпіталізованих хворих. У структурі серцевих новоутворювань міксоми становлять 80-90\% доброякісних пухлин серця.

Мета дослідження - визначити особливості тактики діагностики і хірургічного лікування первинних пухлин серця.

Матеріали і методи. У ДУ НІССХ імені М. М. Амосова НАМН України за період з 1.01.1969 по 1.01.2019 рр. 939 пацієнтів було прооперовано з приводу первинних пухлин серця. Міксоми серця (МС) виявлені у 838 $(89,2 \%)$ хворих, із них у $738(88,1 \%)$ випадках - МС лівого передсердя (ЛП). Міксоми правого передсердя (ПП) визначалися в $73(8,7 \%)$ спостереженнях, МС у лівому (ЛШ) і в правому (ПЖ) шлуночку - по 8 (1,0\%) випадків відповідно. Мультицентричне зростання пухлини з ураженням двох або трьох камер серця було виявлено в 11 (1,3\%) хворих. Вік хворих із МС склав від 3 до 78 років (у середньому 47,5 $\pm 3,4$ р.), вік $608(72,5 \%)$ пацієнтів становив від 31 до 60 років.

Неміксомні доброякісні пухлини спостерігалися в $35(3,7 \%)$ випадках. Злоякісні пухлини спостерігалися в $66(7,0 \%)$ випадках.

Результати. До III і IV функціональних класів за класифікацією NYНА були віднесені 304 (36,3\%) і 71 (8,5\%) пацієнт відповідно, що в цих групах часто потребувало невідкладного хірургічного лікування.

Госпітальна летальність за останні 18 років склала 0\% при хірургічному лікуванні МС, тобто 475 операцій виконано без летальних наслідків.

Висновки. Прийнята тактика невідкладної діагностики та хірургічного втручання забезпечує ефективність лікування міксом серця, що підтверджується даними віддалених результатів: у I ФК NYНА знаходилися 626 (78,4\%) пацієнтів, у ІІ ФК - 118 (14,6\%) пацієнтів; виживання пацієнтів у терміни до 20 років становило 79,7\%.
\end{abstract}

Ключові слова: міксома, доброякісні пухлини серия, хірургічне лікування.

Первинні пухлини серця (ППС) проявляються різноманітною клінічною картиною, що імітує інші захворювання серця. У структурі серцевих новоутворювань міксоми становлять 80-90\% доброякісних пухлин серця. Частота діагностики ППС, з яких понад $80 \%$ є морфологічно доброякісними пухлинами, становить від $0,09 \%$ до $1,9 \%$ до загального числа госпіталізованих хворих [1, 2]. Клінічні прояви виявляються переважно на пізніх стадіях захворювання, крім того, без хірургічного лікування прогноз при цій патології залишається несприятливим. Питання діагностики новоутворень серця і їх адекватного, нерідко екстреного хірургічного лікування залишаються актуальними [3-5].

Мета - визначити особливості діагностики та хірургічного лікування первинних пухлин серця.

Матеріали і методи. У НІССХ імені М. М. Амосова НАМН України за період з 1.01.1969 по 1.01.2019 pp. спостерігалося 939 пацієнтів із морфологічно верифікованими первинними пухлинами серця. Злоякісні пухлини спостерігалися в $66(7,0 \%)$ випадках. Неміксоматозні доброякісні пухлини серця (НДПС) спо- стерігалися в $35(3,7 \%)$ випадках. Рабдоміоми склали $8(22,9 \%)$ випадків, $8(22,9 \%)$ - гемангіоми, $9(25,7 \%)$ папілярні фіброеластоми, ліпоми виявлено у 2 випадках $(5,7 \%)$, фіброми - в $4(11,4 \%)$, лейоміофіброми - в $3(8,6 \%)$ випадках і незріла тератома - в $1(2,9 \%)$ випадку. Вік пацієнтів становив від 1 дня до 67 років (у середньому $34,5 \pm 4,3$ р.).

Міксоми серця (МС) виявлені у $838(89,2 \%)$ хворих: у $738(88,1 \%)$ випадках - МС лівого передсердя (ЛП). Міксоми правого передсердя (ПП) визначалися в 73 (9,2\%) спостереженнях, МС у лівому (ЛШ) і в правому (ПЖ) шлуночках - по $8(1,0 \%)$ випадків відповідно. Мультицентричне зростання пухлини з ураженням двох або трьох камер серця було виявлено в $11(1,4 \%)$ хворих. Вік хворих із МС становив від 3 до 78 років (у середньо-

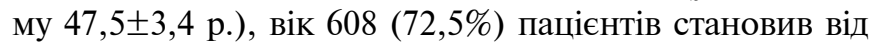
31 до 60 років.

Результати та обговорення. У результаті спостережень визначено збільшення частоти реєстрації хворих із МС у НICCX імені М. М. Амосова НАМН України: за період з 1969 по 1990 рр. кількість пацієнтів із МС дорівнювала 
$160(19,1 \%)$, а за період з 1991 по 2019 рр. - 778 (80,9\%), шо зумовлено як широким впровадженням у діагностику ультразвукового дослідження серця, так і ймовірним збільшенням частоти цього захворювання.

Застійна серцева недостатність була основним клінічним проявом захворювання, що пояснюється частковою обтурацією пухлиною клапанних отворів із подальшим розвитком порушення гемодинаміки у відповідних камерах серця, яка визначалася у $775(92,5 \%)$ пацієнтів із МС. До III і IV функціональних класів за класифікацією NYHА віднесені 304 (36,3\%) і 71 (8,5\%) пацієнт відповідно, що в цих групах часто потребувало невідкладного хірургічного лікування. Діаметр основи МС становив від 0,5 до 7,5 см. При цьому в $724(86,4 \%)$ випадках переважним місцем фіксації МС була міжпередсердна перегородка (МПП).

Важливими клінічними симптомами МС були напади запаморочення і непритомності, які визначалися у $181(21,6 \%)$ хворого. У $118(14,1 \%)$ пацієнтів поява цих симптомів була пов'язана з певним положенням тіла, що виявилося характерним для передсердної локалізації пухлин і не спостерігалося у випадках шлуночкової локалізації МС.

Таке важке ускладнення клінічного перебігу захворювання, як емболічний синдром, визначалося у хворих із МС у 45 (5,4\%) випадках, причому на тлі синусового ритму. У цих пацієнтів емболія судин головного мозку мала місце в $36(4,3 \%)$ випадках, з яких в $9(1,1 \%)$ - багаторазово. У $9(1,1 \%)$ хворих була зареєстрована емболія судин інших органів - судин нирок, нижніх і верхніх кінцівок. Болі в ділянці серця реєструвалися у $313(37,4 \%)$ хворих iз різноманітними локалізаціями МС. Найчастіше болі проявлялися як відчуття тяжкості в грудній клітці і не носили стенокардитичного характеру. У $732(87,4 \%)$ випадках тривалість симптомів захворювання не перевищувала 1 року до операції. Прояви недостатності кровообігу при МC (задишка, серцебиття, запаморочення, непритомність) були різного ступеня - залежно від положення тіла хворого в $227(27,1 \%)$ спостереженнях.

При аускультативному дослідженні у хворих із МС виявлялися шуми, подібні до таких при ревматичних пороках серця. Мінливість аускультативних проявів при стабільно синусовому ритмі з часом і при зміні положення тіла пацієнта була визначальною, що зумовлено зміщенням пухлини щодо клапанів серця, і відзначена у $161(19,2 \%)$ пацієнта. Різні порушення ритму, як клінічні прояви МС, виявлялися у 249 (29,8\%) пацієнтів. Слід зауважити, що у $188(22,4 \%)$ хворих вони виявлялися стійкою (117 випадків $(13,9 \%))$ або пароксизмальною (71 $(8,5 \%)$ випадок) тахіаритмією в поєднанні з екстрасистолією.

Загальна слабкість, швидка стомлюваність і нездужання у $525(62,7 \%)$ хворих, субфебрилітет у 473 (56,4\%) випадках визначалися як клінічні прояви МC; артралгія та міальгія - у $262(31,2 \%)$, зниження маси тіла - у $325(38,8 \%)$ пацієнтів були розцінені як загальна реакція організму на пухлину.

ЕхоКГ $є$ основним діагностичним методом у комплексі діагностики ППС. 3838 пацієнтів із МС у 795 (94,9\%), починаючи з 1984 р., була проведена ЕхоКГ. У цій когорті у $542(68,2 \%)$ випадках пухлина візуалізувалася у вигляді неоднорідного за своєю структурою об'ємного утворення пористого характеру з розпливчастими нерівними контурами, які змінювалися в процесі руху. В інших $253(31,8 \%)$ випадках візуалізувалося об'ємне новоутворення гомогенного характеру з чіткими рівними краями. У 59 (7,4\%) випадках визначалися вкраплення кальцію у вигляді яскравих ехо-сигналів різноманітної локалізації. Основа МС виявлялася у 648 $(81,5 \%)$ пацієнтів: у $504(63,4 \%)$ випадках місце прикріплення пухлини визначалося на ділянці МПП.

Виражені клінічні прояви, наявні під час транспортування та укладання пацієнтів на операційному столі і пов'язані з обтурацією клапанних отворів при підготовці до операції, мали місце у 48 (5,8\%) хворих із МС. У таких випадках було визнано за доцільне надавати пацієнтам напівсидяче положення з поворотом на правий бік на початку хірургічного втручання.

Усі операції, за винятком 15 (1,8\%), які виконувалися на ранньому етапі хірургії МС і одного втручання з правобічної міні-торакотомії в 2015 р., проводили доступом із серединної стернотомії, що забезпечило оптимальні умови для видалення пухлин будь-якої локалізації. Різні хірургічні доступи застосовувалися при видаленні МС ЛП і відрізнялися різною частотою фрагментації новоутворень при їх видаленні. Застосування лівопередсердного доступу в 128 $(15,3 \%)$ випадках МС ЛП супроводжувалося фрагментацією МС у $49(38,1 \%)$ пацієнтів. Традиційний доступ до МС ЛП через ПП і МПП виявився найбільш зручним, при цьому реєструвалося зменшення частоти фрагментації пухлини до 21,1\% (136 хворих на 638 операцій). У 8 (1,0\%) пацієнтів з МС ЛП ми були змушені застосувати комбінований доступ правої атріотомії та септотомії з лівою атріотомією, що дозволило безпечно закінчити операцію. У $48(5,7 \%)$ випадках при виявленні великих (до 8-12 см) міксом ЛП застосовувався черездвохпередсердний доступ, який дозволив практично повністю уникнути фрагментації пухлини.

При макроскопічному дослідженні МС було визначено, що пухлинами були ворсинчасті - в $484(57,7 \%)$ випадках і компактні новоутворення овоїдної або округлої форми, з блискучою гладкою, іноді горбистою поверхнею - в 354 (42,3\%) випадках відповідно.

Супутня патологія клапанного апарату при МС визначалася у $69(8,2 \%)$ хворих. У 41 (4,9\%) випадку спостерігалося ізольоване ураження мітрального клапана (MK), в 25 (3,0\%) - трикуспідального клапана (ТК), у $2(0,2 \%)$ випадках - ураження аортального клапана, в 1 випадку $(0,1 \%)$ - поєднане ураження мітрального та аортального клапанів. У цій когорті пацієнтів механічне ушкодження клапанних структур міксомою виявлено 
у 28 (3,3\%) хворих. Інша патологія клапанного апарату проявилася відносною недостатністю клапана за рахунок вираженого розширення фіброзного кільця: трикуспідального - в 24 (2,9\%) і мітрального - у $16(1,9 \%)$ випадках. Залучення клапанного апарату в пухлинний процес спостерігалося у $8(1,0 \%)$ хворих. При цьому в $1(0,1 \%)$ пацієнта міксома ПЖ прикріплювалася до папілярних м'язів і хорд ТК, а в $7(0,9 \%)$ випадках міксоми ЛП вражали передню стулку МК. Хірургічна корекція клапанних уражень була виконана у $68(8,1 \%)$ хворих: у $14(1,7 \%)$ випадках - протезування клапанів (11 - МК, 1 - ТK, 1 - AK, 1 - АK+МK), в 44 (5,3\%) - пластичні операції з позитивним функціональним ефектом.

Госпітальна летальність за останні 18 років склала 0\% при хірургічному лікуванні МС: 475 операцій виконано без летальних наслідків. Однак слід визначити, що до 2000 року, на період становлення тактики хірургічного лікування МС, госпітальна летальність дорівнювала 4,6\% (39 випадків). Причинами летальних наслідків були неврологічні ускладнення - у 16 (46,2\%) хворих; матеріальна емболія - в $7(17,9 \%)$ випадках, інфаркт міокарда - в $3(7,7 \%)$ випадках; септичні ускладнення - в $1(2,6 \%)$ випадку; похибки операцій - в 5 (12,9\%) випадках.

У віддаленому періоді вивчено результати хірургічного лікування МС у 718 пацієнтів (89,6\% виписаних) у терміни від 6 місяців до 47 років (у середньому 19,5 $\pm 4,2$ року). Виживання в терміни до 20 років становило $79,7 \%$. У віддаленому періоді в I ФК NYHA знаходилися $626(78,4 \%)$ пацієнтів, у ІІ ФК - 118 (14,8\%). Рецидиви МС виявлені у $17(2,1 \%)$ пацієнтів у терміни від 2 до 12 років (у середньому $3,5 \pm 0,4$ р.) після первинної операції. При цьому в 4 випадках рецидиву МС $(23,5 \%)$ мав місце міксомний синдром.
При хірургічному лікуванні НДПС госпітальна летальність склала 2,9\% (1 випадок). У віддаленому періоді загинули два пацієнти, рецидивів захворювання в перші роки після операції не було виявлено.

Висновки. За останні 18 років виконано 475 операцій із приводу МС без летальних наслідків, що зумовлено особливостями тактики невідкладної діагностики та хірургічного лікування, що знижує частоту доопераційних ускладнень і забезпечує безпеку і радикальність видалення пухлин серця.

Прийнята тактика забезпечує ефективність хірургічного лікування міксом серця, шо підтверджується даними віддалених результатів: у I ФК NYHA знаходилися $626(78,4 \%)$ пацієнтів, у ІІ ФК - $118(14,6 \%)$ пацієнтів; виживання в терміни до 20 років склало 79,7\%.

\section{Література}

1. Anvari MS, Naderan M et al. Clinicopathologic Review of Non-Myxoma Cardiac Tumors: A 10-Year Single-Center Experience. Cardiology. 2014;129:199-202.

2. Vitovskiy R, Isaienko V et al. The Tactics of Safe Removal of Heart Myxomas; The Experience of 796 Operations. E Journal of Cardiovascular Medicine 2018;06(2):56-59. Doi: $10.15511 /$ ejcm.18.00256

3. Hoffmeier A, Sindermann JR, Scheld HH et al. Cardiac tumors-diagnosis and surgical treatment. Deutsches Ärzteblatt International. 2014;111(12):205-11.

4. Habertheuer A, Laufer G, Wiedemann D. et al. Primary cardiac tumors on the verge of oblivion: a European experience over 15 years. J Cardiothorac Surg. 2015; 10:56-60.

5. Isogai T, Yasunaga $H$, Matsui $H$. et al. Factors affecting in-hospital mortality and likelihood of undergoing surgical resection in patients with primary cardiac tumors. J Cardiol. 2016;10:1016.

\title{
Peculiarities of tactics of surgical treatment of primary benigh heart tumours
}

\author{
Vitovsky R. M., Isaienko V. V., Onishchenko V. F., Pishchurin O. A., Dyadyun D. M.
}

National M. M. Amosov Institute of Cardiovascular Surgery National Academy of Medical Sciences of Ukraine (Kyiv)

The frequency of diagnosing primary heart tumours (PHT), of which more than $80 \%$ are morphologically benign tumours, ranges from $0.09 \%$ to $1.9 \%$ of the total number of hospitalized patients. In the structure of cardiac neoplasms, myxoma constitute $80-90 \%$ of benign heart tumours.

The objective of the study is to determine the peculiarities of tactics of diagnosis and surgical treatment of primary heart tumours.

Material and methods. 939 patients underwent surgical interventions for primary cardiac tumours in M.M. Amosov Institute of Cardiovascular Surgery of the Academy of Medical Sciences of Ukraine for the period from January 1, 1969 to January 1, 2019. Cardiac myxomas (CM) were diagnosed in 838 (89.2\%) patients, of which left atrial (LA) CM in $738(88.1 \%)$ cases. The right atrial (RA) myxomas were diagnosed in $73(8.7 \%)$ cases, left ventricular (LV) and right ventricular (RV) CM - in $8(1.0 \%)$ cases, respectively. Multicentric tumour growth with damage to two or three cardiac chambers was found in $11(1.3 \%)$ patients. The age of patients with CM was from 3 to 78 years (on average $47.5 \pm 3.4$ ), the age of $608(72.5 \%)$ patients ranged from 31 to 60 years.

Non-myxomic benign tumours were observed in $35(3.7 \%)$ cases, malignant tumours - in 66 (7.0\%) cases.

Results and discussion. 304 (36.3\%) and 71 (8.5\%) patients had NYHA classes III and IV, respectively, which often required urgent surgical treatment in these groups.

Hospital mortality over the past 18 years was $0 \%$ in CM surgical treatment, namely, 475 operations were performed without lethal outcomes.

Conclusions. The accepted tactics of urgent diagnosis and surgical intervention ensure the efficacy of cardiac myxoma treatment, as evidenced by long-term findings: 626 (78.4\%) patients had NYHA class I, 118 (14.6\%) patients had NYHA class II respectively. 20 -year survival rate was observed in $79.8 \%$ cases.

Key words: myxomas, benign heart tumours, surgical treatment. 